\title{
Relationships between domains of functioning of workers with work-related disorders
}

\section{Correlação entre domínios de funcionalidade de trabalhadoras com doenças musculoesqueléticas relacionadas ao trabalho}

(D) Ana Clarissa Lopes Silva Damasceno ${ }^{1}$, (D) Lauro Antonio Porto², Denise Nunes Viola ${ }^{3}$, (Dionna Bernardes ${ }^{2}$, (D) Robson da Fonseca Neves ${ }^{4}$, Monica Angelim Gomes de Lima²

1 Master in Health, Environment and Work for Graduate Program in Health, Environment and Work, School of Medicine, Universidade Federal da Bahia - UFBA

2 PHD in Public Health, Graduate Program in Health, Environment and Work, School of Medicine, Universidade Federal da Bahia - UFBA

3 PHD in Estatistic, Statistics Department, Universidade Federal da Bahia - UFBA

${ }^{4}$ PHD in Public Health, Graduate Program in Physical Therapy, Universidade Federal da Paraíba - UFPB

Address for correspondence

Robson da Fonseca Neves

E-mail: robsonfisioba@gmail.com

Submitted: September 22, 2020

Accepted: October 5, 2020

\section{How to cite}

Damasceno ACLS, Porto LA, Viola DN, Bernardes K, Neves RF, Lima MAG. Relationships between domains of functioning of workers with workrelated disorders. Acta Fisiatr. 2020;27(3):152 159

DOI: 10.11606/issn.2317-0190.v27i3a174902

\section{cc) (1) (2)}

(C)2020 by Acta Fisiátric

This work is licensed under a Creative Commons Attribution 4.0 International

\begin{abstract}
Workers with work-related musculoskeletal disorders (WMDs) have impairments in the body functions and structures, and have difficulty performing daily activities and developing social participation. Environmental factors can act negatively or positively as barriers or facilitators, worsening or improving the health status of people. This study assessed the relationship between health domains, based on components of body functions, activities and participation and environmental factors of non-statutory and statutory workers with WMDS. The negative relationships were stronger between mental and sensory functions and pain and activities/participation and environmental factors of non-statutory workers. The relationships signaled that the more impairments, the more difficulties. Environmental factors such as temperature, vibration and attitudes hindered mental and sensory functions and pain.
\end{abstract}

Keywords: Musculoskeletal Diseases, Occupational Diseases, Cumulative Trauma Disorders, International Classification of Functioning, Disability and Health

\section{RESUMO}

Trabalhadoras com doenças musculoesqueléticas (DME) relacionadas ao trabalho possuem deficiências relacionadas às funções e estruturas do corpo, bem como têm dificuldades para executar atividades do cotidiano no âmbito individual e social. Somado a isso, os fatores do ambiente podem atuar como barreiras ou facilitadores, agravando ou melhorando o estado de saúde das pessoas. Objetivou-se verificar a correlação entre alguns domínios da saúde, que pertencem aos componentes das funções do corpo, atividades e participação e fatores ambientais de trabalhadoras estatutárias e não estatutárias com DME. Houve maior correlação negativa entre as funções mentais e sensoriais e de dor com as atividades e participação e fatores ambientais de trabalhadoras não estatutárias. As correlações indicaram que a funcionalidade das trabalhadoras não estatutárias esteve mais prejudicada, bem como as correlações positivas sinalizaram que maiores deficiências repercutiram em mais dificuldades na atividade e participação social. Quanto aos fatores ambientais como temperatura, vibração e atitudes foram obstáculos às funções mental e sensorial e de dor.

Palavras-chave: Doenças Musculosqueléticas, Doenças do Trabalho, Transtornos Traumáticos Cumulativos, Classificação Internacional de Funcionalidade, Incapacidade e Saúde 


\section{INTRODUCTION}

Work-related musculoskeletal disorders (WMDS) are caused both by physical aspects, such as repetitive strain and the prolonged static postures, and by psychosocial aspects of work, such as monotony, low control and pressure to perform work activities. ${ }^{1}$ The disorders cause symptoms as paresthesia, pain and sensation of heaviness, and are responsible for contributing to psychic problems. ${ }^{2}$ The complexity of WMDS is many times related to a disability which requires a multidisciplinary treatment, with emphasis on reducing physical and psychic problems and minimizing the difficulties caused in the many activities and participation in daily life. ${ }^{3}$

The sense of disability coming from the limitations contributes to the appearance of psychic problems. ${ }^{3,4}$ Such fact is part of the process of becoming ill with a chronic musculoskeletal disease, caused by the interaction between physical harm and psychological suffering, which depends both on biomechanical demands and on stress regularly occurred at the work environment. ${ }^{5}$

The psychological suffering causes more limitations in the daily activities. When it is associated to pain, the quality of life is worse. ${ }^{6}$ Pain, when chronic, may be related to depression, anxiety, decrease in social participation, irritability, fatigue and sleep disorders. The presence of mental disorders may interfere negatively in the care of people with chronic pain, as well as negatively influence their health status. ${ }^{7}$

Fear of unemployment can make many people keep working feeling pain. To try to soothe it, workers, frequently, use analgesics. ${ }^{8,9}$ The perpetuation of the injury, without proper treatment to recover the body structure, causes frequent pain-causing stimuli, contributing to the illness becoming chronic. ${ }^{4,5}$ Moreover, the medical assessment of individuals with chronic affections to confirm incapacity for work is frequently focused on the individual's physical or mental limitations. It does not consider the barriers and facilitators of the environment, the family context, the workplace and the social factors. ${ }^{8,9}$

In 2001, the World Health Organization proposed the International Classification of Functioning, Disability and Health (ICF), which has as an objective to describe the health status based on the components: body functions and structures, activities and participation, and environmental factors. The components are constituted by a series of health domains and encompass categories which permit the verification of the functioning of individuals. ${ }^{10}$

Theoretical and methodological efforts have been made to make the use of ICF possible in the many services for evaluation and management of a wide variety of health situations and conditions. In the field of occupational health in Brazil, we can highlight the Protocolo de Avaliação da Funcionalidade de Trabalhadores com LER/DORT (Protocol of Assessment of Functioning of Workers with RSL/WRMD - Repetitive Strain Lesion / Work-related Musculoskeletal Disorder), which aims at researching the biopsychosocial demands of workers with a diagnosis of RSL/WRMD, on the basis of a methodological triangulation developed based on narrative interviews about the process of becoming ill, psychometric instruments and the RSL/WRMD Checklist. ${ }^{11}$

The latest is made of categories selected from ICF and has as an objective to describe the functioning of workers. This diagnosis guides the individual therapeutic plan to return to work. ${ }^{11}$

WMDS appear in workers of different occupations. ${ }^{12,13}$ In Brazil, both non-statutory workers, ${ }^{14}$ prevalent in private companies, and statutory workers, who are public servants and have an employment relationship regulated by Law $\mathrm{n}$ 은 $8.112 / 1990$, suffer from such disorders. ${ }^{15}$

Non-statutory workers and public servants have rights such as benefits, pensions, aids, retirement benefits and leaves. However, the statutory ones have a condition differentiated from other workers, since they have the right to stability at their jobs, higher income and more access to multidisciplinary health care with support from public and private health providers. ${ }^{16}$ The question that guides this study is: is there a difference in functioning between these workers? Statutory and non-statutory workers with WMDS, possibly, show different health status. This inequality is represented mainly by greater impairments found in the mental and sensory functions and pain ${ }^{17}$ of non-statutory workers.

\section{OBJECTIVE}

The objective was to compare the degree of functioning of female non-statutory and statutory workers with WMDS and check for the existence of a relationship between the health domains in both groups of workers.

\section{METHODS}

This is a cross sectional analytical study. The data come from a sample of 40 female workers with a diagnosis of WMDS, with a nonrandom sample of health services users, who had functional symptoms and disorders of upper limbs and the cervical area, served in the following institutions: Ambulatório de Dor Crônica do Hospital das Clínicas da Universidade Federal da Bahia (HUPES/UFBA) (Chronic Pain Clinic of Hospital das Clínicas of Federal University of Bahia), Centro Estadual de Referência em Saúde do Trabalhador (CESAT) (Occupational Health Reference Center of the State of Bahia), Departamento de Terapia Ocupacional da Escola Bahiana de Medicina e Saúde Pública (SERTO/EBMSP) (Department of Occupational Therapy of Escola Bahiana de Medicina e Saúde Pública) and Regional Labor Court of the 5th region, all located in the State of Bahia, Brazil.

The data were obtained based on the Protocolo de Avaliação da Funcionalidade de Trabalhadores com LER/DORT (Protocol of Assessment of Functioning of Workers with RSL/WRMD). ${ }^{11}$ The primary data were collected between years 2007 and 2009. Eighteen non-statutory female workers and 22 statutory female workers took part in the study.

The functioning profile was analyzed based on 77 categories distributed among the components, body functions, activities and participation and environmental factors of the RSL/WRMD Checklist $^{11}$ (Chart 1).

Each category was, first, qualified based on the workers' answers. Body functions and structures were classified as no impairment (0), mild (1), moderate (2), severe (3), complete (4) impairment. Activities and participation were categorized as no difficulty (0), mild (1), moderate (2), severe (3), complete (4) difficulty. 
Chart 1. Domains and categories from RSL/WRMD Core Set analyzed in the research of functioning of non-statutory and statutory female workers with work-related musculoskeletal disorders, served in occupational health clinics in Bahia, Brazil from 2007 to 2009

\begin{tabular}{|c|c|}
\hline Domains & Categories \\
\hline Mental functions & $\begin{array}{l}\text { b126 Temperament and personality; b1300 Level of energy; b1301 Motivation; b1340 Amount of sleep; } \\
\text { b1342 Maintenance of sleep; b1343 Quality of sleep; b140 Attention function; b144 Memory functions; b152 } \\
\text { Emotional functions; b1801 Body image }\end{array}$ \\
\hline Sensory and pain functions & $\begin{array}{l}\text { b260 Proprioceptive function; b265 Tactile function; b2700 Sensitivity to temperature; b280 Function of } \\
\text { sensation of pain; b2801 Function of localized pain; b28010 Headache or pain in the neck; b28014 Pain in } \\
\text { upper limbs; b28016 Pain in the joints; b2802 pain in multiple parts of the body; b2803 radiating pain in a } \\
\text { dermatome; b2804 Radiating pain in a segment or area }\end{array}$ \\
\hline Application of knowledge & d177 Making decisions \\
\hline General tasks and demands & d230 Performing daily routine; d240 Dealing with stress and other psychological demands \\
\hline Mobility & $\begin{array}{l}\text { d415 Maintaining body posture; d430 Raising and carrying objects; d440 Fine hand movements; d445 Use } \\
\text { hand and arm; d450 Walking; d470 Use of transportation; d475 Driving }\end{array}$ \\
\hline Self-care & $\begin{array}{l}\text { d510 Washing oneself; d520 Caring for body parts; d540 Getting dressed; d550 Eating; d570 Caring for own } \\
\text { health }\end{array}$ \\
\hline Domestic life & $\begin{array}{l}\text { d630 Preparing meals; d640 Performing domestic tasks; d650 Caring for household objects; d660 Helping } \\
\text { others }\end{array}$ \\
\hline $\begin{array}{l}\text { Interactions and interpersonal } \\
\text { relationships }\end{array}$ & d720 Complex interpersonal relationships; d760 Family relationships; d770 Intimate relationships \\
\hline Main areas of life & $\begin{array}{l}\text { d825 Vocational training; d830 Higher education; d845 Getting, keeping and leaving a job; d850 Paid work; } \\
\text { d855 Unpaid work }\end{array}$ \\
\hline Community, social and civic life & d910 Community life; d920 Recreation and leisure; d930 religion and spiritual life \\
\hline Products and technology & $\begin{array}{l}\text { e1101 Medication; e115 Products and technology for personal use in daily life; e120 Products and } \\
\text { technologies for mobility in indoor and outdoor environments; e1350 General products and technologies for } \\
\text { work; e1351 Products and technologies of assistance to work; e1650 Financial assets; e1651 Material goods; } \\
\text { e1652 non-material goods }\end{array}$ \\
\hline $\begin{array}{l}\text { Natural environment and man- } \\
\text { made changes }\end{array}$ & e2250 Temperature; e255 Vibration \\
\hline Support and relationships & $\begin{array}{l}\text { e310 Immediate family; e315 Extended family; e320 Friends; e325 Acquaintances, colleagues, neighbors and } \\
\text { members of the community; e330 People in position of authority, e340 Personal care providers; e355 Health } \\
\text { professionals; e360 Health related professionals }\end{array}$ \\
\hline Attitudes & $\begin{array}{l}\text { e410 Individual attitudes from immediate family; e } 415 \text { Individual attitudes from extended family; e420 } \\
\text { Individual attitudes from friends; e } 425 \text { Individual attitudes from acquaintances, colleagues, neighbors and } \\
\text { members of the community; e } 430 \text { Individual attitudes from people in position of authority; e } 450 \text { Individual } \\
\text { attitudes from health professionals; e } 455 \text { Individual attitudes from other professionals; e460 Social attitudes; } \\
\text { e465 Social policies, practices and ideologies }\end{array}$ \\
\hline
\end{tabular}

Environmental factors were classified as facilitators and/or barriers, being classified as no barrier (0), mild (-1), moderate $(-2)$, severe $(-3)$, complete $(-4)$ barrier. The facilitator was classified as: no (0), mild (+1), moderate $(+2)$, considerable $(+3)$, complete (+4). When the quantifiers of barriers and facilitators occurred at the same time for the same category, they were added.

Later, the categories were grouped in their respective domains, as follows:

$$
I_{d}=\frac{X_{1}+X_{2}+\cdots+X_{c}}{n}
$$

In this equation, $I_{d}$ represents the index for each domain, $X(1,2, \ldots, c)$ the qualifier for the categories and $n$ the number of existing categories per domain.

The third stage was developed by quantifying the domains of the RSL/WRMD Checklist, with the score: no impairment

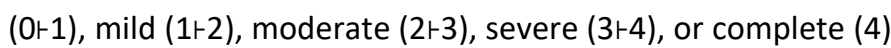
impairment. Activities and participation included no difficulty $(0 \vdash 1)$, mild $(1-2)$, moderate $(2 \vdash 3)$, severe $(3-4)$, complete $(4)$ difficulty. Environmental factors were scored as: no barriers $(0+1)$, mild (-1--2), moderate (-2r-3), severe (-3r-4), complete (4) barrier; or no facilitator $(0+1)$, mild $(+1++2)$, moderate $(+2++3)$, considerable $(+3++4)$, complete $(+4)$ facilitator.

The database was built in the statistical package SPSS, version $13 .{ }^{18}$ The sample series test was employed to check the randomness of the records obtained, ${ }^{19}$ whose result was compatible with the randomness of the samples. Aiming at characterizing the female workers according to the type of contract (Statutory/non-statutory) it was performed a bivariate descriptive analysis with socio-demographic, occupational and health care variables.

The Spearman correlation test was performed for the nonparametric independent samples of statutory and nonstatutory workers with WMDS and it was verified the existence of relationship between mental and sensory functions and pain and the domains of activities and participation and environmental factors of the RSL/WRMD Core Set.

All measures were taken to establish respect, protect the identity, promote beneficence and non-maleficence of workers 
and provide confidentiality of the data, according to Resolution no 466/12 from Brazil's National Health Council. ${ }^{20}$

The Project was approved by the Research Ethics Committee of Escola Bahiana de Medicina e Saúde Pública, of Salvador, Bahia, Brazil with Protocol number 64/2009.

\section{RESULTS}

As we stratified the statutory female worker per type of contract, they were characterized as most being over 45 years (58.8\%), without a partner $(57.9 \%)$, with higher educational attainment (undergraduate) and income, and shorter leave (28.6\%).

Non-statutory workers mostly had (77.8\%) lower level of education and up to 18 years of occupation time (57.9\%) and $57.1 \%$ were away from work in the moment of the collection. Social security status was equivalent for both types, public social security (Table 1). Mental and sensory functions and pain were positively related in both groups, more clearly in the nonstatutory workers group (Figures 1 and 2).

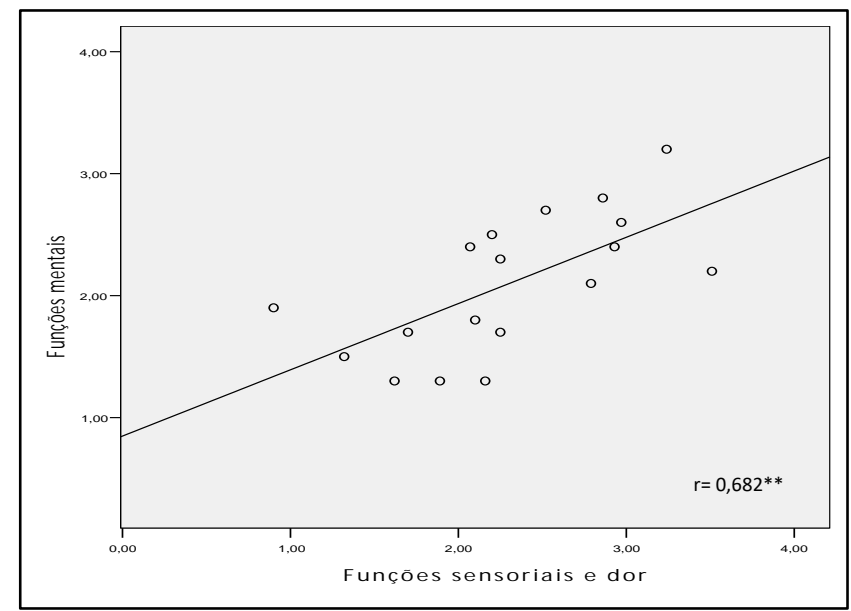

Figure 1. Relationships between mental and sensory functions and pain of non-statutory female workers with work-related musculoskeletal disorders, served in occupational health clinics in Bahia, Brazil from 2007 to 2009

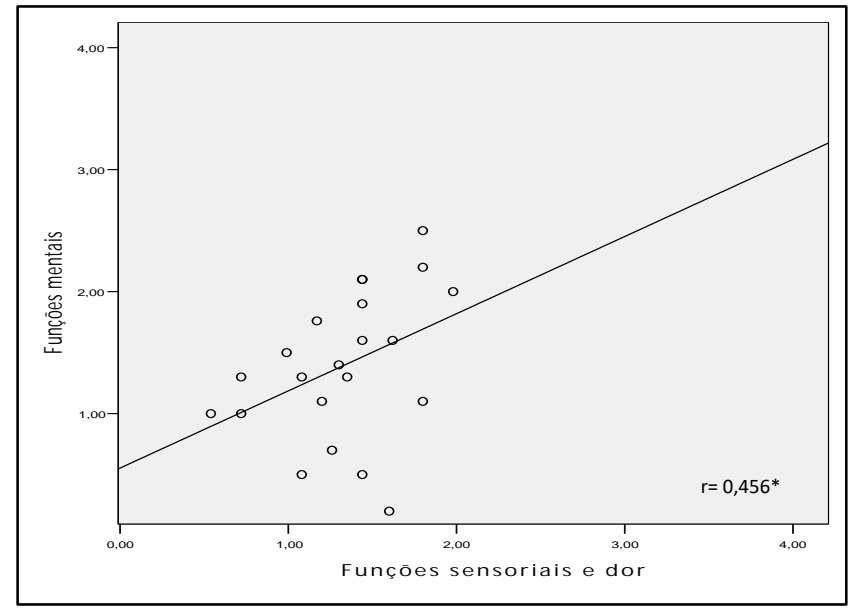

Figure 2. Relationships between mental and sensory functions and pain of statutory female workers with work-related musculoskeletal disorders, served in occupational health clinics in Bahia, Brazil from 2007 to 2009
Table 1. Sociodemographic, occupational and health care characteristics of female workers with work-related musculoskeletal disorders according to type of contract, served in occupational health clinics in Bahia, Brazil from 2007 to 2009

\begin{tabular}{|c|c|c|c|c|}
\hline \multirow{2}{*}{ Characteristics } & \multicolumn{2}{|c|}{ Statutory } & \multicolumn{2}{|c|}{ Non-statutory } \\
\hline & $\mathbf{n}$ & $\%$ & $\mathbf{n}$ & $\%$ \\
\hline \multicolumn{5}{|l|}{ Age (40) } \\
\hline Over 45 years & 10 & 58.8 & 7 & 41.2 \\
\hline Under 45 years & 12 & 52.2 & 11 & 47.8 \\
\hline \multicolumn{5}{|l|}{ Marital status (39) } \\
\hline With a partner & 11 & 55.0 & 9 & 45.0 \\
\hline Without a partner & 11 & 57.9 & 8 & 42.1 \\
\hline \multicolumn{5}{|l|}{ Education (38) } \\
\hline High school & 4 & 22.2 & 14 & 77.8 \\
\hline Undergraduate & 16 & 84.2 & 3 & 15.8 \\
\hline \multicolumn{5}{|l|}{ Income (39) } \\
\hline 1 to 5 minimum wages & 0 & 0 & 17 & 100 \\
\hline 6 minimum wages or more & 22 & 100 & 0 & 0 \\
\hline \multicolumn{5}{|l|}{ Occupation time (38) } \\
\hline Up to 18 years & 8 & 42.1 & 11 & 57.9 \\
\hline 19 years or more & 13 & 68.4 & 6 & 31.6 \\
\hline \multicolumn{5}{|l|}{ Absent from work (40) } \\
\hline No & 16 & 84.2 & 3 & 38.5 \\
\hline Yes & 6 & 28.6 & 15 & 57.1 \\
\hline \multicolumn{5}{|l|}{ Social security status (38) } \\
\hline Public Social Security & 20 & 55.6 & 16 & 44.4 \\
\hline Private Social Security & 2 & 100 & 0 & 0 \\
\hline
\end{tabular}

The non-statutory female workers' records showed a positive relationship between mental functions and the many domains of activities and participation, including application of knowledge, general tasks and demands, mobility, self-care, domestic life and main areas of life. Sensory and pain functions were related positively with mobility, self-care, domestic life and main areas of life (Table 2).

The analyses of the statutory workers showed a positive relationship between mental functions and general tasks and demands, domestic life, and community, social and civic life. Sensory and pain functions were positively related with mobility, self-care, domestic life, and community, social and civic life (Table 3).

When linking mental and sensory functions and pain of nonstatutory workers with environmental factors domains, one could verify that there was a negative relationship with attitudes, the natural environment and man-made changes. The analyses of the statutory workers indicated a negative relationship between sensory and pain functions and products and technology (Table 2).

\section{DISCUSSION}

Based on the analyses of functioning of non-statutory and statutory female workers, it was possible to evidence that there was a greater relationship between the health domains among the non-statutory ones. Such fact suggests that they had greater disability. Considering the stratification in Table 1 , we can observe that the non-statutory ones are younger, with less time in the job and disabled early in life, which denotes greater personal, social and economic impact. 
Table 2. Relationships between activities and participation domains and mental and sensory functions and pain of non-statutory and statutory female workers with work-related musculoskeletal disorders, served in occupational health clinics in Bahia, Brazil from 2007 to 2009

\begin{tabular}{|c|c|c|c|c|c|c|c|c|}
\hline \multirow{3}{*}{$\begin{array}{l}\text { Activities and } \\
\text { participation }\end{array}$} & \multicolumn{4}{|c|}{ Mental Functions } & \multicolumn{4}{|c|}{ Sensory and Pain Functions } \\
\hline & \multicolumn{2}{|c|}{ Non-statutory workers } & \multicolumn{2}{|c|}{ Statutory workers } & \multicolumn{2}{|c|}{ Non-statutory workers } & \multicolumn{2}{|c|}{ Statutory workers } \\
\hline & $\begin{array}{l}\text { Correlation } \\
\text { coefficient }\end{array}$ & $p$ value & $\begin{array}{l}\text { Correlation } \\
\text { coefficient }\end{array}$ & $p$ value & $\begin{array}{l}\text { Correlation } \\
\text { coefficient }\end{array}$ & p value & $\begin{array}{l}\text { Correlation } \\
\text { coefficient }\end{array}$ & p value $*$ \\
\hline $\begin{array}{l}\text { Application of } \\
\text { knowledge }\end{array}$ & 0.691 & $0.001 * *$ & 0.321 & 0.078 & 0.248 & 0.082 & 0.353 & 0.058 \\
\hline Tasks and demands & 0.591 & $0.005^{* *}$ & 0.601 & $0.002 * *$ & 0.342 & 0.082 & 0.318 & 0.080 \\
\hline Mobility & 0.688 & $0.001 * *$ & 0.165 & 0.237 & 0.544 & $0.010 * *$ & 0.444 & $0.022 * *$ \\
\hline Self-care & 0.459 & $0.028 * *$ & 0.188 & 0.207 & 0.457 & $0.028 * *$ & 0.730 & $0.000 * *$ \\
\hline Domestic life & 0.459 & $0.028 * *$ & 0.405 & $0.038 * *$ & 0.556 & $0.008 * *$ & 0.474 & $0.017 * *$ \\
\hline $\begin{array}{l}\text { Interactions and } \\
\text { relationships }\end{array}$ & 0.750 & 0.384 & 0.338 & 0.067 & 0.220 & 0.190 & 0.195 & 0.199 \\
\hline Main areas of life & 0.525 & $0.018 * *$ & 0.180 & 0.231 & 0.659 & $0.003 * *$ & 0.262 & 0.139 \\
\hline $\begin{array}{l}\text { Community, social and } \\
\text { civic life }\end{array}$ & 0.139 & 0.291 & 0.397 & $0.038 * *$ & 0.241 & 0.168 & 0.594 & $0.002 * *$ \\
\hline
\end{tabular}

*Spearman correlation test $p$ value; **statistical significance test at 0.05

Table 3. Relationships between environmental factors domains and mental and sensory functions and pain of non-statutory and statutory female workers with work-related musculoskeletal disorders, served in occupational health clinics in Bahia, Brazil from 2007 to 2009

\begin{tabular}{|c|c|c|c|c|c|c|c|c|}
\hline \multirow{3}{*}{ Environmental factors } & \multicolumn{4}{|c|}{ Mental Functions } & \multicolumn{4}{|c|}{ Sensory and Pain Functions } \\
\hline & \multicolumn{2}{|c|}{ Non-statutory workers } & \multicolumn{2}{|c|}{ Statutory workers } & \multicolumn{2}{|c|}{ Non-statutory workers } & \multicolumn{2}{|c|}{ Statutory workers } \\
\hline & $\begin{array}{l}\text { Correlation } \\
\text { coefficient }\end{array}$ & $p$ value & $\begin{array}{l}\text { Correlation } \\
\text { coefficient }\end{array}$ & $p$ value & $\begin{array}{c}\text { Correlation } \\
\text { coefficient }\end{array}$ & $p$ value & $\begin{array}{l}\text { Correlation } \\
\text { coefficient }\end{array}$ & p value * \\
\hline Products and technology & -0.189 & 0.226 & -0.223 & 0.166 & -0.372 & 0.064 & -0.484 & $0.013^{* *}$ \\
\hline $\begin{array}{l}\text { Natural environment and man- } \\
\text { made changes }\end{array}$ & -0.531 & $0.012 * *$ & 0.300 & 0.093 & -0.729 & $0.000 * *$ & 0.229 & 0.159 \\
\hline Support and relationships & 0.174 & 0.245 & 0.084 & 0.359 & -0.197 & 0.216 & -0.054 & 0.408 \\
\hline Attitudes & -0.402 & $0.049 * *$ & 0.114 & 0.312 & -0.625 & $0.003^{* *}$ & -0.201 & 0.191 \\
\hline
\end{tabular}

*Spearman correlation test $p$ value; **statistical significance test at 0.05

Lower income and work leave signal a more advanced stage of the illness and of the disability condition. The relationships indicated that, probably, the impairments resulted in difficulties and the psychological suffering caused greater harm to pain sensations or vice versa.

Non-statutory female workers' mental and sensory functions and pain may have been worsened by attitudes of people in society, thermal discomfort and vibration. Positive relationships were found between mental and sensory functions and pain of non-statutory and statutory workers, evidences that are in accord with records in the literature, when they assert that mental health directly interferes in the level of pain ${ }^{21}$ or that the sensation of pain may cause psychological suffering. ${ }^{7}$

When there is a relationship between these aspects, problems in social participation, general health status and vitality are bigger, and the quality of life is worse. ${ }^{6}$ The chronic illness is associated with mental problems and when combined with painful sensations they constantly result in incapacity for work, ${ }^{22}$ limitations in daily activities and social participation. ${ }^{5}$

Statutory female workers have greater social support, both because of their higher income which facilitates the access to health and other professionals, and because of their employment stability, a fact that fosters mental health. ${ }^{17}$

Low social support and low satisfaction and stress at work were harmful to the mental health of low-income workers. ${ }^{23}$ Workers' psychological well-being and pain complaints depend on social support, compensation system, work environment and the individual's personal factors. When these aspects are unfavorable, they can, in combination, enhance the disability. ${ }^{24,25}$ On the other hand, social helplessness may foster more musculoskeletal pain complaints by workers, resulting in information bias. ${ }^{26}$

Non-statutory workers' lower income, lack of social care and fear of unemployment may contribute for the severity of the lesion, overuse of analgesics, greater number of leaves and prolonged absence from work. ${ }^{21}$ The threat of unemployment, the competitive work environment, the necessity to work to 
guarantee enough income for subsistence and the low perspective about social reintegration influence the feeling of despair, worsening these workers' suffering and making them more vulnerable. ${ }^{27}$

Most non-statutory female workers were on work leave. Such fact may be related to the low support provided to return to work and the occupational rehabilitation not matching the needs of workers with chronic pain. ${ }^{16,28}$

When workers with WMDS do not have health care performed by a multidisciplinary team, their health condition is worsened. This contributes to the prolonged absence from their job and predisposes the appearance of mental disorders such as depression. ${ }^{16}$

The analyses show relationships between sensory and pain functions with mobility, self-care and domestic life for nonstatutory and statutory workers. In other words, possibly, the greater the sensory impairment had been, the greater difficulty there was to perform the activities. Such fact coincides with other scientific studies when they assert that workers in pain have greater limitation to perform daily activities, ${ }^{29}$ such as domestic activities and personal hygiene. ${ }^{30}$

In both groups there were relationships between mental functions and domestic life and tasks and demands, which include performing daily routine and dealing with stress and other psychological demands. The psychiatric disorder interferes negatively in the capacity of facing the existing impairments.

Such fact contributes to the disability. ${ }^{31}$ The greater psychological suffering also causes more limitations in the daily activities, as well as results in greater harm to painful sensations. ${ }^{6}$

Non-statutory female workers' mental functions were related to: application of knowledge, which encompasses the capacity to make decisions; mobility; self-care; main areas of life, which includes vocational training; higher education; getting, keeping and leaving a job; paid and unpaid work. For statutory workers there was an indication that the mental functions may result in difficulties in community, social and civic life, which contemplates community life, recreation and leisure, religion and spiritual life. The greater impairment of the non-statutory workers may have contributed to their worse health condition, fact which is in accord with the relationships, when they were greater as they associated mental functions and activities and participation. According to the ICF, body functions and structures directly impact the activities and participation of the individual. ${ }^{10}$

There were relationships between sensory and pain functions and the main areas of life and community, social and civic life for non-statutory and statutory workers, respectively. This difference is linked to the non-statutory ones' painful sensations which may result in difficulties in the main areas of life.

Among others, these areas involve aspects connected to professional performance, which may be compromised by pain. ${ }^{32}$ Statutory workers have employment stability, fact that may have corroborated to considering greater harm in participation, which contemplates religion, community life, recreation and leisure.

Mental and sensory functions and pain of non-statutory female workers showed negative relationship with attitudes, natural environment and man-made changes that involved temperature and vibration. The statutory ones' sensory and pain functions had a negative relationship with products and technology. The non-statutory workers' body functions, possibly, were more aggravated by vibration, temperature and attitudes of people in society. Obstacles like products and technologies for work may have contributed to the appearance of the statutory workers' musculoskeletal symptoms.

The barriers may act negatively in the functioning of individuals. ${ }^{10}$ Factors that influence the effectiveness of work, such as thermal discomfort, vibrations, high humidity, inadequate equipment, conflict with peers and supervisors, cause occupational stress ${ }^{33}$ and contribute to dissatisfaction at work. ${ }^{34}$ Beliefs and attitudes, also, interfere negatively, increasing the painful sensations. ${ }^{31}$

The worsening of symptoms contributes to decreasing the work performance, which makes the relation with bosses and supervisors difficult. The invisibility of the process of becoming ill with WMDs fosters the low understanding about the health status, which may cause negative attitudes from work peers, family and friends, decreasing social support. ${ }^{31}$ On the other hand, the support from family members aids in the decrease of stress and increases the quality of life. ${ }^{29}$

Among the limitations of the study, there is the fact that it is not possible to know what the relation between cause and effect is in the relationships found, as well as it is not applicable to extend the associations to the population of non-statutory and statutory female workers with WMDS. However, the results found signal the importance of the biopsychosocial approach with the finality to size the impact of WMDS on the life of female workers.

\section{CONCLUSION}

When the functioning of non-statutory and statutory female workers was analyzed, it was possible to verify that there was greater involvement in the health status of the nonstatutory ones, evidenced by the greater relationship between the health domains. The impairments in mental and sensory functions may have resulted in difficulties to perform daily tasks and social participation or vice versa, also such functions may be worsened by environmental factors.

The results show the importance of the multidisciplinary approach aiming at minimizing sensory and mental problems, with emphasis on reducing barriers which, probably, fosters the occurrence of incapacity for work. The mental function of non-statutory female workers was more related to the domains of activities and participation, signaling greater impairment, which results in more difficulties to perform daily tasks.

Attitudes, temperature and vibration possibly interfered negatively in the mental and sensory functions and pain of nonstatutory workers, which compromises their health condition. Products and technologies that aid daily life, positive attitudes of people in society, natural environment and beneficial manmade changes may preserve the body functions of female workers with WMDS.

The process of rehabilitation of workers aiming at improving the biopsychosocial aspects may increase functioning and, consequently, foster the return to work. 


\section{REFERENCES}

1. Hagberg M, Violante FS, Bonfiglioli R, Descatha A, Gold J, Evanoff $B$, et al. Prevention of musculoskeletal disorders in workers: classification and health surveillance statements of the Scientific Committee on Musculoskeletal Disorders of the International Commission on Occupational Health. BMC Musculoskelet Disord. 2012;13:109. Doi: https://doi.org/10.1186/14712474-13-109

2. Brasil. Ministério da Saúde. Diagnóstico, tratamento, reabilitação, prevenção e fisiopatologia das LER/DORT. Brasília (DF): Ministério da Saúde; 2001.

3. Jansen GB, Linder J, Ekholm KS, Ekholm J. Differences in symptoms, functioning, and quality of life between women on long-term sick-leave with musculoskeletal pain with and without concomitant depression. J Multidiscip Healthc. 2011;4:281-92.

Doi: https://doi.org/10.2147/JMDH.S21827

4. Vlaeyen JW, Linton SJ. Fear-avoidance model of chronic musculoskeletal pain: 12 years on. Pain. 2012;153(6):1144-7.

https://doi.org/10.1016/i.pain.2011.12.009

5. Vader K, Doulas T, Patel R, Miller J. Experiences, barriers, and facilitators to participating in physical activity and exercise in adults living with chronic pain: a qualitative study. Disabil Rehabil. 2019:1-9. Doi: https://doi.org/10.1080/09638288.2019.1676834

6. Bair MJ, Poleshuck EL, Wu J, Krebs EK, Damush TM, Tu W, et al. Anxiety but not social stressors predict 12-month depression and pain severity. Clin J Pain. 2013;29(2):95101.

Doi:

https://doi.org/10.1097/AJP.0b013e3182652ee9

7. Bras $M$, Dordević $V$, Gregurek $R$, Bulajić $M$. Neurobiological and clinical relationship between psychiatric disorders and chronic pain. Psychiatr Danub. 2010;22(2):221-6.

8. Cullen KL, Irvin E, Collie A, Clay F, Gensby U, Jennings PA, et al. Effectiveness of workplace interventions in returnto-work for musculoskeletal, pain-related and mental health conditions: an update of the evidence and messages for practitioners. J Occup Rehabil. 2018;28(1):115. Doi: https://doi.org/10.1007/s10926-016-9690-x

9. Dijkers MP, Murphy SL, Krellman J. Evidence-based practice for rehabilitation professionals: concepts and controversies. Arch Phys Med Rehabil. 2012;93(8 Suppl):S164-76.

Doi: https://doi.org/10.1016/j.apmr.2011.12.014

10. CIF: Classificação Internacional de Funcionalidade, Incapacidade e Saúde. São Paulo: Edusp; 2003.

11. Lima MAG, Neves RF, Tironi MOS, Nascimento AMDN, Magalhães FB. Avaliação da funcionalidade dos trabalhadores com LER/DORT: a construção do Core Set da CIF para LER/DORT. Acta Fisiatr. 2008;15(4):229-35.

12. Kathy Cheng HY, Cheng CY, Ju YY. Work-related musculoskeletal disorders and ergonomic risk factors in early intervention educators. Appl Ergon. 2013;44(1):13441. Doi: https://doi.org/10.1016/i.apergo.2012.06.004
13. Gitkind Al, Gritsenko K. Neck pain. In: Yong RJ, Nguyen M, Nelson E, (ed). Pain Medicine. Cham: Springer; 2017. p. 453-5. Doi: https://doi.org/10.1007/978-3-319-43133$\underline{8 \quad 119}$

14. Brasil. Decreto-Lei n. 5.452, de 1 de maio de 1943. Aprova a Consolidação das Leis do Trabalho. Diário Oficial da República Federativa do Brasil, Brasília (DF); 1943 Ago 9 [Citado 2020 Ago 21]. Disponível em: http://www.planalto.gov.br/ccivil 03/decretolei/del5452compilado.htm

15. Brasil. Lei n. 8.112, de 11 de dezembro de 1990. Dispõe sobre o regime jurídico dos servidores públicos civis da União, das autarquias e das fundações públicas federais. Diário Oficial da República Federativa do Brasil, Brasília (DF); 1991 Abr 19 [Citado 2020 Ago 21]. Disponível em: http://www.planalto.gov.br/ccivil 03/leis/18112cons.htm

16. Traesel ES, Merlo ÁRC. "Somos sobreviventes": vivências de servidores públicos de uma instituição de seguridade social diante dos novos modos de gestão e a precarização do trabalho na reforma gerencial do serviço público. Cad Psicol Soc Trab. 2014;17(2):224-38. Doi: https://doi.org/10.11606/issn.1981-0490.v17i2p224-238

17. Varekamp I, van Dijk FJ, Kroll LE. Workers with a chronic disease and work disability. Problems and solutions. Bundesgesundheitsblatt Gesundheitsforschung Gesundheitsschutz. 2013;56(3):406-14. Doi: https://doi.org/10.1007/s00103-012-1621-1

18. Statistical Package for the Social Sciences [programa de computador] Versão 13.0. Chicago: IBM; 2004.

19. Siegel $\mathrm{S}$, Castellan JNJ. Estatística não-paramétrica para ciências do comportamento. Porto Alegre: Artmed; 2006.

20. Brasil. Conselho Nacional de Saúde (CNS). Resolução no 466, de 12 de dezembro de 2012. Aprova as seguintes diretrizes e normas regulamentadoras de pesquisas envolvendo seres humanos [texto na Internet]. Diário Oficial da Republica Federativa do Brasil, Brasília (DF): 2013 Jun 13; Seção 1:59-62.

21. Turner JA, Franklin G, Fulton-Kehoe D, Egan K, Wickizer TM, Lymp JF, et al. Prediction of chronic disability in workrelated musculoskeletal disorders: a prospective, population-based study. BMC Musculoskelet Disord. 2004;5:14. Doi: https://doi.org/10.1186/1471-2474-5-14

22. Mojtabai R, Stuart EA, Hwang I, Susukida R, Eaton WW, Sampson N, Kessler RC. Long-term effects of mental disorders on employment in the National Comorbidity Survey ten-year follow-up. Soc Psychiatry Psychiatr Epidemiol. 2015;50(11):1657-68. Doi: https://doi.org/10.1007/s00127-015-1097-z

23. Saldanha JHS, Lima MAG, Neves RF, Iriart JAB. Construção e desconstrução das identidades masculinas entre trabalhadores metalúrgicos acometidos de LER/DORT. Cad Saúde Pública 2018;34(5):e00208216. Doi: http://dx.doi.org/10.1590/0102-311x00208216

24. Aragón A, Partanen T, Felknor S, Corriols M. Social determinants of workers' health in Central America. Int J Occup Environ Health. 2011;17(3):230-7. Doi: https://doi.org/10.1179/107735211799041986 
25. Turk DC, Wilson HD. Fear of pain as a prognostic factor in chronic pain: conceptual models, assessment, and treatment implications. Curr Pain Headache Rep. 2010;14(2):88-95. Doi: https://doi.org/10.1007/s11916010-0094-X

26. Woolf AD, Vos T, March L. How to measure the impact of musculoskeletal conditions. Best Pract Res Clin Rheumatol. 2010;24(6):723-32. Doi: https://doi.org/10.1016/i.berh.2010.11.002

27. Bridi MA, Braga R, Santana MA. Sociologia do trabalho no Brasil hoje: balanço e perspectivas. Rev Bras Sociol. 2018;6(12):42-64.

Doi: http://dx.doi.org/10.20336/rbs.244

28. de Vries HJ, Brouwer S, Groothoff JW, Geertzen JH, Reneman MF. Staying at work with chronic nonspecific musculoskeletal pain: a qualitative study of workers' experiences. BMC Musculoskelet Disord. 2011;12:126. Doi: https://doi.org/10.1186/1471-2474-12-126

29. Neves RF, Nunes MO. Da legitimação a (res)significação: o itinerário terapêutico de trabalhadores com LER/DORT. Ciênc Saúde Coletiva. 2010;15(1):211-20. Doi: https://doi.org/10.1590/S1413-81232010000100026
30. Lima MAG, Trad LAB. "Circuloterapia": uma metáfora para o enfrentamento da dor crônica em duas clínicas de dor. Physis: Rev Saúde Coletiva. 2011;21(1):217-36. Doi: https://doi.org/10.1590/S0103-73312011000100013

31. Sardá Júnior JJ, Nicholas MK, Pimenta CAM, Asghari A. Preditores biopsicossociais de dor, incapacidade e depressão em pacientes brasileiros com dor crônica. Rev Dor. 2012;13(2):111-8. Doi: https://doi.org/10.1590/S1806-00132012000200003

32. Maeno M, Vilela RAG. Reabilitação profissional no Brasil: elementos para a construção de uma política pública. Rev Bras Saúde Ocup. 2010;35(121):87-99. Doi: http://dx.doi.org/10.1590/S0303-76572010000100010

33. Venugopal V, Chinnadurai JS, Lucas RA, Kjellstrom T. Occupational Heat Stress Profiles in Selected Workplaces in India. Int J Environ Res Public Health. 2015;13(1):89. Doi: https://doi.org/10.3390/ijerph13010089

34. Brauer M, Gradim MN, Silva NG, Braun F. Satisfação no trabalho: aspectos conceituais e metodológicos. Rev Vianna Sapiens. 2018;9(1):137-58. Doi: https://doi.org/10.31994/rvs.v9i1.335 